\title{
Colloidal Synthesis of Tunable Copper Phosphide Nanocrystals
}

\author{
Alexander G. Rachkov and Alina M. Schimpf* \\ Department of Chemistry and Biochemistry, University of California, San Diego, La Jolla, CA \\ 92093, USA \\ *Electronic address: aschimpf@ucsd.edu
}

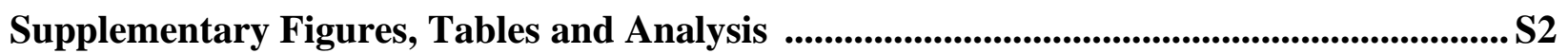

Figure S1. Absorption spectra of $\mathrm{Cu}_{3-x} \mathrm{P}$ nanocrystals from three synthetic methods ............ S2

Figure S2. ${ }^{31} \mathrm{P}-\mathrm{NMR}$ spectra of reaction supernatants from three synthetic methods............. S2

Figure S3. $\mathrm{Cu}_{3-x} \mathrm{P}$ synthesis with no primary amine …………………………………...... S3

Table S1. Times and temperatures of aliquots taken to monitor $\mathrm{Cu}_{3-x} \mathrm{P}$ nanocrystal growth . S3

Figure S4. Powder X-ray diffraction patterns of aliquots ................................................... S4

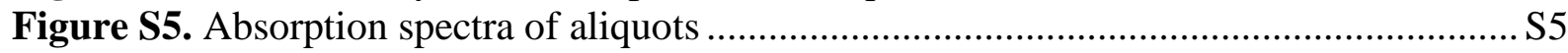

Figure S6. Mass spectra of species present during nanocrystal syntheses ............................ S6

Section S1. Additional mass spectral analysis ................................................................... 7

Figure S7. ${ }^{31} \mathrm{P}-\mathrm{NMR}$ evaluation of species present during $\mathrm{Cu}_{3-x} \mathrm{P}$ nanocrystal synthesis....... S8

Figure S8. ${ }^{31} \mathrm{P}-\mathrm{NMR}$ evaluation of $\mathrm{Cu}$-aminophosphine complexation .............................. S9

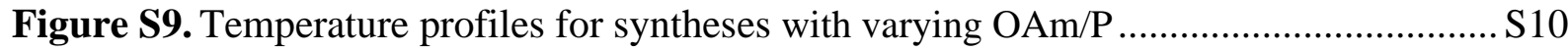

Table S2. Tabulated data for nanocrystals synthesized with varying OAm/P......................... S10

Table S3. Yields and nucleation activities for representative $\mathrm{Cu}_{3-x} \mathrm{P}$ syntheses ................... S11

Figure S10. Temperature profiles for syntheses with varying $\mathrm{P} / \mathrm{Cu}$.................................. S12

Table S4. Tabulated data for nanocrystals synthesized with varying $\mathrm{P} / \mathrm{Cu}$............................ S12

Figure S11. Characterization of $\mathrm{Cu}_{3-x} \mathrm{P}$ nanocrystals synthesized in octadecane ................ S13

Figure S12. Additional characterization for low-temperature synthesis .............................. S14

Table S5. Tabulated data for nanocrystals synthesized with different temperature profiles.... S14

Figure S13. $\mathrm{Cu}_{3-x} \mathrm{P}$ nanocrystals synthesized using a two-part temperature profile .............. S15

Figure S14. Comparison of temperature profiles with $\mathrm{OAm} / \mathrm{P} / \mathrm{Cu}=4.9 / 1.4 / 1.0 \ldots \ldots \ldots \ldots \ldots \ldots . . . \mathrm{S} 16$

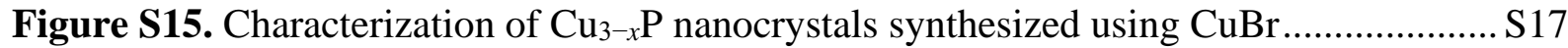

Table S6. Comparison of syntheses with different $\mathrm{CuX}\left(\mathrm{X}^{-}=\mathrm{Cl}^{-}, \mathrm{Br}^{-}\right)$........................... S17

Figure S16. Formation of $\mathrm{Cu}(0)$ in a synthesis with $\mathrm{OAm} / \mathrm{P} / \mathrm{Cu}=30.4 / 1.4 / 1.0 \ldots \ldots \ldots \ldots \ldots \ldots . . \mathrm{S} 18$

Figure S17. NMR evaluation of $\mathrm{OAm}-\mathrm{P}\left(\mathrm{NEt}_{2}\right)_{3}$ ligand-exchange …............................... 18

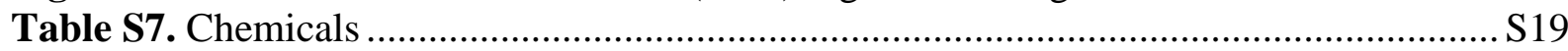

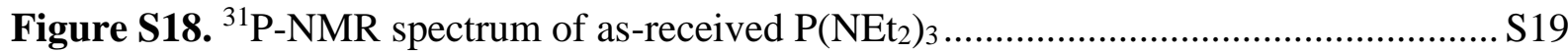

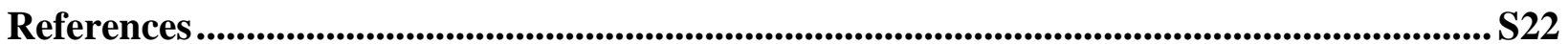




\section{Supplementary Figures, Tables and Analysis}

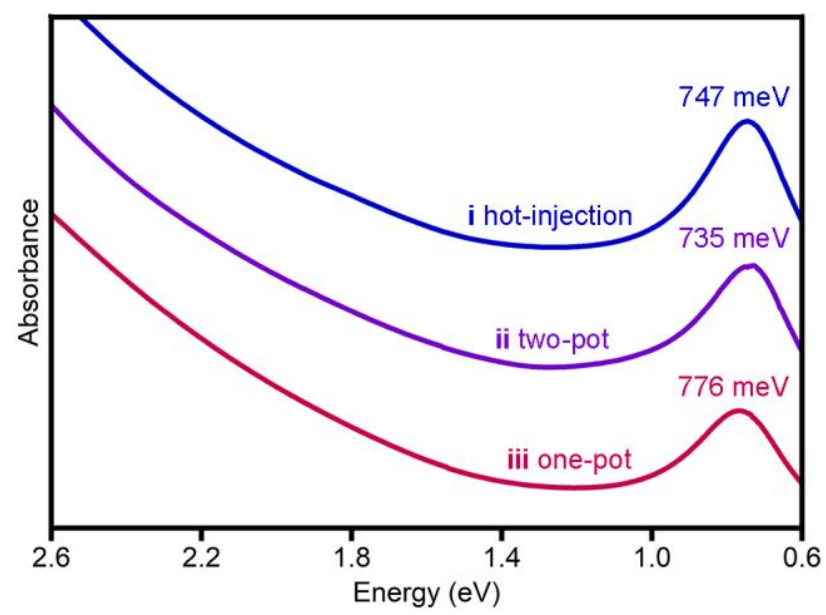

Figure S1. Absorption spectra of $\mathrm{Cu}_{3-x} \mathrm{P}$ nanocrystals synthesized with $[\mathrm{Cu}]=$ $0.100 \mathrm{M}, \mathrm{OAm} / \mathrm{P} / \mathrm{Cu}=24.0 / 3.0 / 1.0$ and $T_{\mathrm{f}} \approx 280{ }^{\circ} \mathrm{C}$ using three different methods (Figure 1): (i) "hot-injection" (injection of $\mathrm{P}\left(\mathrm{NEt}_{2}\right)_{3}$ at $T_{\text {inj }}=215^{\circ} \mathrm{C}$ ), (ii) "two-pot" (injection of pre-transaminated phosphine at $T_{\mathrm{inj}}=215^{\circ} \mathrm{C}$ ) and (iii) "one-pot" heatup.

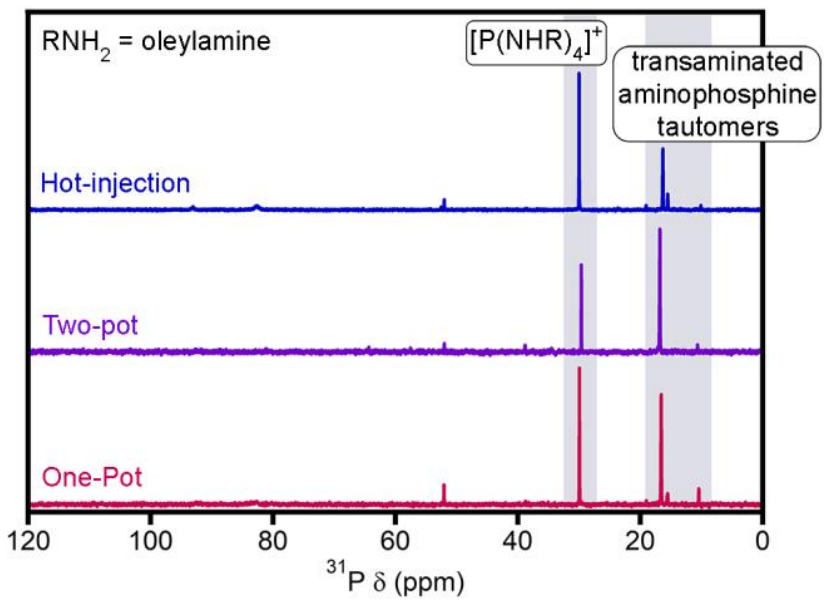

Figure S2. ${ }^{31} \mathrm{P}-\mathrm{NMR}$ spectra of post-reaction supernatants for $\mathrm{Cu}_{3-x} \mathrm{P}$ nanocrystals synthesized with $[\mathrm{Cu}]=0.100 \mathrm{M}, \mathrm{OAm} / \mathrm{P} / \mathrm{Cu}=24.0 / 3.0 / 1.0$ and $T_{\mathrm{f}} \approx 280^{\circ} \mathrm{C}$ using three different methods (Figure 1): (i) "hot-injection" (injection of $\mathrm{P}\left(\mathrm{NEt}_{2}\right)_{3}$ at $T_{\mathrm{inj}}$ $=215{ }^{\circ} \mathrm{C}$ ), (ii) "two-pot" (injection of pre-transaminated phosphine at $T_{\mathrm{inj}}=215$ ${ }^{\circ} \mathrm{C}$ ) and (iii) "one-pot" heat-up. The "transaminated aminophosphine tautomers" region may also contain small amounts of aminophosphine oxide, which is present in the starting material, $\mathrm{P}\left(\mathrm{NEt}_{2}\right)_{3}$ (Figure $\mathrm{S} 18$ ). 

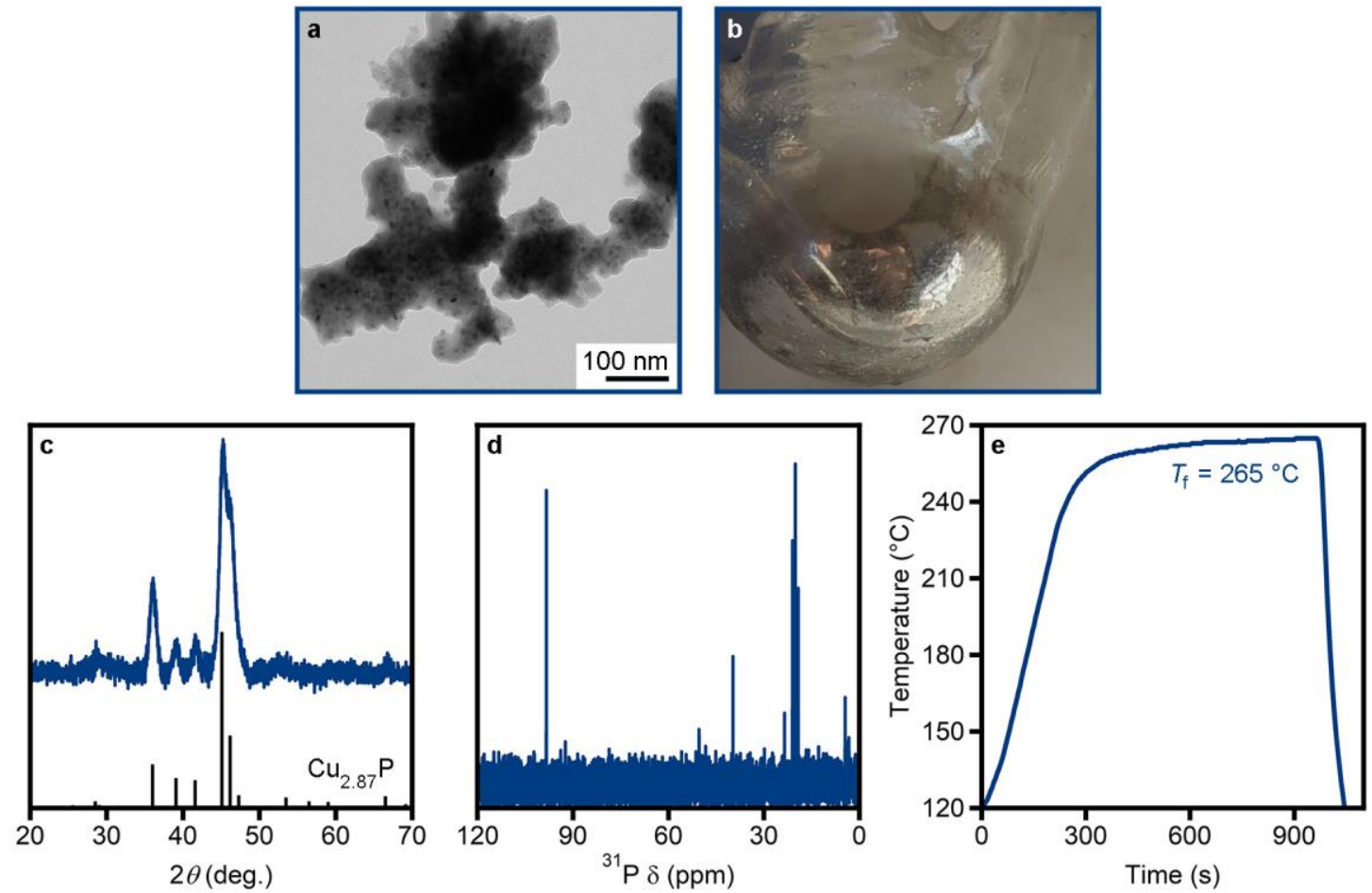

Figure S3. $\mathrm{Cu}_{3-x} \mathrm{P}$ nanocrystal synthesis using $\mathrm{P}\left(\mathrm{NEt}_{2}\right)_{3}$ and TOA with no primary amine $\left([\mathrm{Cu}]=0.100 \mathrm{M}, \mathrm{TOA} / \mathrm{P} / \mathrm{Cu}=22.8 / 3.0 / 1.0, T_{\mathrm{f}}=265^{\circ} \mathrm{C}\right)$. (a) $\mathrm{TEM}$ image of nanocrystal product. (b) Photograph of metallic film formed on the reaction flask. (c) Powder X-ray diffraction pattern of the nanocrystal product compared to that simulated for $\mathrm{P}_{3} \mathrm{~cm} \mathrm{Cu}_{2.87} \mathrm{P}$ (ref. 1). (d) The ${ }^{31} \mathrm{P}-\mathrm{NMR}$ spectrum of the reaction supernatant does not show typical byproducts (Figure S2). (e) Temperature profile of the reaction.

Table S1. Time and temperature of aliquots taken during a one-pot synthesis of $\mathrm{Cu}_{3-x} \mathrm{P}$ nanocrystals with $[\mathrm{Cu}]=0.100 \mathrm{M}, \mathrm{OAm} / \mathrm{P} / \mathrm{Cu}=24.0 / 3.0 / 1.0$ and $T_{\mathrm{f}}=300{ }^{\circ} \mathrm{C}$ (Figure 2).

Time following start

\begin{tabular}{ccc} 
Aliquot & of nucleation (s) & Temperature $\left({ }^{\circ} \mathbf{C}\right)$ \\
\hline 1 & 45 & 255 \\
2 & 125 & 273 \\
3 & 350 & 287 \\
4 & 560 & 292
\end{tabular}




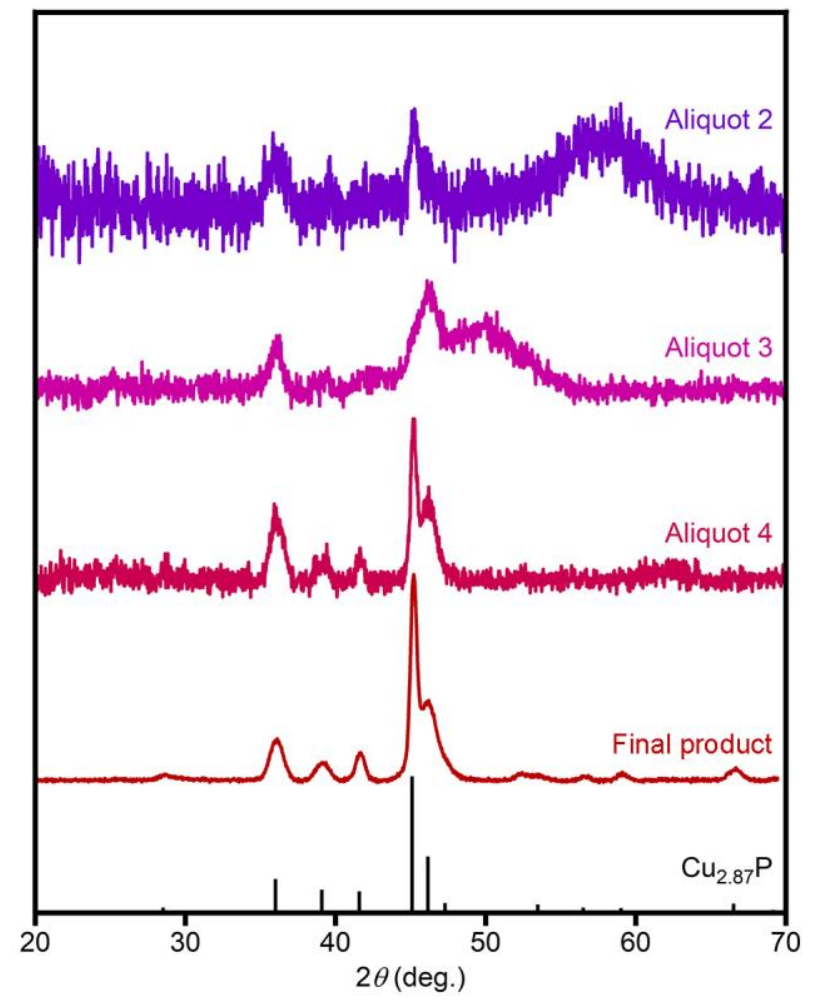

Figure S4. Powder X-ray diffraction patterns of the aliquots and final product collected from a one-pot synthesis of $\mathrm{Cu}_{3-x} \mathrm{P}$ nanocrystals $([\mathrm{Cu}]=0.100 \mathrm{M}$, $\mathrm{OAm} / \mathrm{P} / \mathrm{Cu}=24.0 / 3.0 / 1.0, T_{\mathrm{f}}=300{ }^{\circ} \mathrm{C}$; Figure 2). The simulated pattern for $\mathrm{P}_{3} \mathrm{~cm}$ $\mathrm{Cu}_{2.87} \mathrm{P}$ (ref. 1) is shown for comparison. Aliquots were collected $45 \mathrm{~s}$ (aliquot 1, no diffraction observed), $125 \mathrm{~s}$ (aliquot 2), $350 \mathrm{~s}$ (aliquot 3) and $560 \mathrm{~s}$ (aliquot 4) after the reaction began to change color ("nucleation"). 

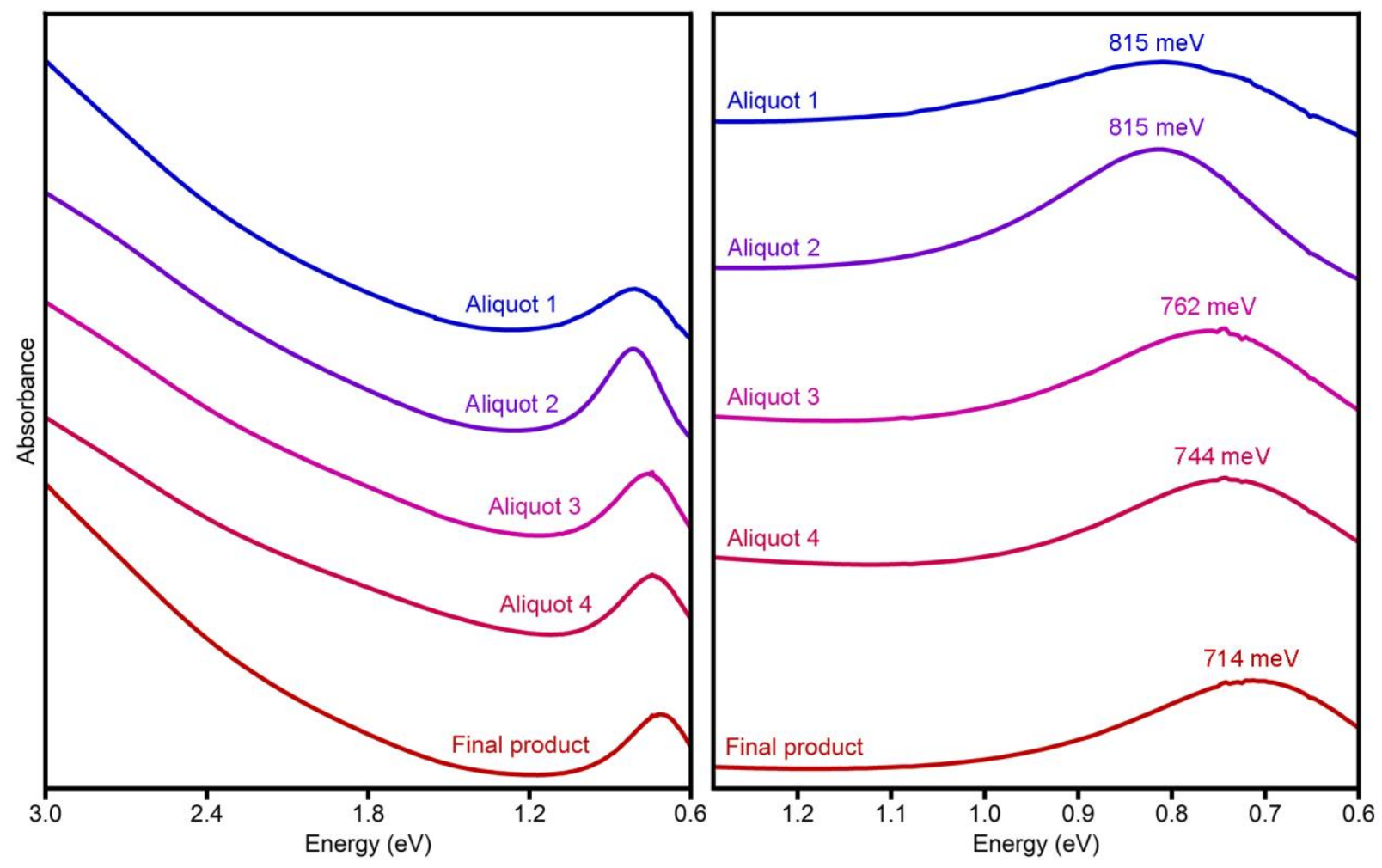

Figure S5. (a) Absorption spectra of the aliquots and final product collected from a one-pot synthesis of $\mathrm{Cu}_{3-x} \mathrm{P}$ nanocrystals $([\mathrm{Cu}]=0.100 \mathrm{M}, \mathrm{OAm} / \mathrm{P} / \mathrm{Cu}=$ 24.0/3.0/1.0, $T_{\mathrm{f}}=300{ }^{\circ} \mathrm{C}$; Figure 2). (b) Magnification of the NIR spectral region. Aliquots were collected $45 \mathrm{~s}$ (aliquot 1), $125 \mathrm{~s}$ (aliquot 2), $350 \mathrm{~s}$ (aliquot 3) and 560 s (aliquot 4) after the reaction began to change color ("nucleation"). The ensemble LSPR red-shifts over the course of the reaction. 


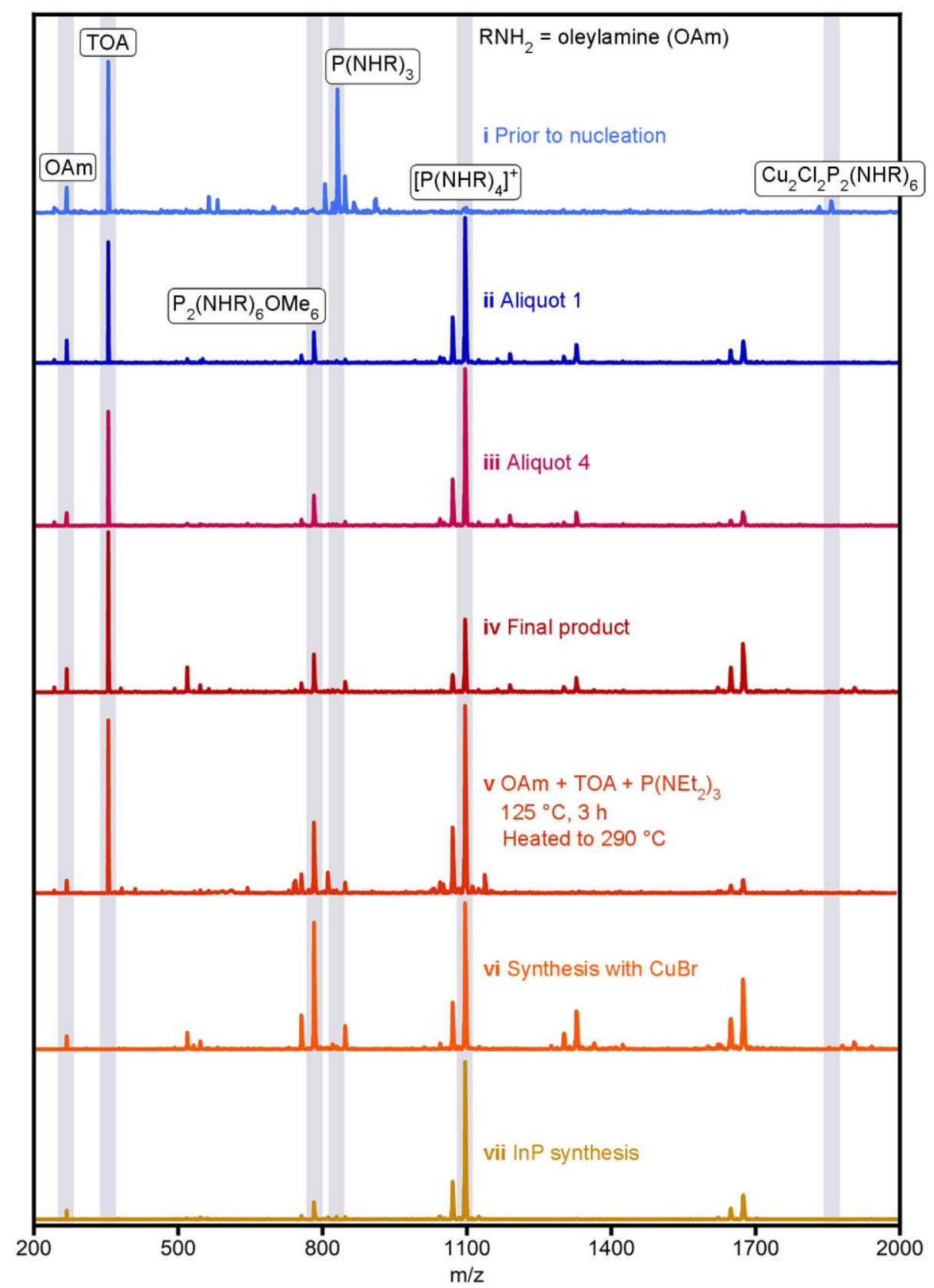

Figure S6. Mass spectra (i-iv) One-pot synthesis of $\mathrm{Cu}_{3-x} \mathrm{P}$ nanocrystals $([\mathrm{Cu}]=$ $0.100 \mathrm{M}, \mathrm{OAm} / \mathrm{P} / \mathrm{Cu}=24.0 / 3.0 / 1.0, T_{\mathrm{f}}=300{ }^{\circ} \mathrm{C}$; Figure 2): (i) Aliquot " $0 "$ collected prior to ramp-up from $125{ }^{\circ} \mathrm{C}$, (ii) supernatant of aliquot 1, (iii) supernatant of aliquot 4 and (iv) the final supernatant. (v) OAm/TOA/P(NEt $)_{3}$ $(8.0 / 2.6 / 1.0)$ degassed at $125{ }^{\circ} \mathrm{C}(3 \mathrm{~h})$ and heated to $290{ }^{\circ} \mathrm{C}$ under Ar. (vi) Supernatant from a one-pot synthesis of $\mathrm{Cu}_{3-x} \mathrm{P}$ nanocrystals using $\mathrm{CuBr}([\mathrm{Cu}]=$ $0.100 \mathrm{M}, \mathrm{OAm} / \mathrm{P} / \mathrm{Cu}=24.0 / 3.0 / 1.0, T_{\mathrm{f}}=295^{\circ} \mathrm{C}$ ). (vii) Supernatant from a hotinjection synthesis of $\operatorname{InP}\left([\operatorname{In}]=0.100 \mathrm{M}, \mathrm{OAm} / \mathrm{P} / \mathrm{In}=30.4 / 4.0 / 1.0, T_{\text {inj }}=230^{\circ} \mathrm{C}\right.$, $\left.T_{\mathrm{f}}=275^{\circ} \mathrm{C}\right)$. 


\section{Section S1: Additional MS analysis}

The solvents, OAm (267 g/mol) and TOA $(354 \mathrm{~g} / \mathrm{mol})$ are present in the pre-nucleation solution and in the supernatants of all aliquots and the final product (Figure S6i-iv). Post-nucleation samples (Figure S6ii-iv) also contain $\mathrm{P}_{2}\left(\mathrm{NHC}_{18} \mathrm{H}_{35}\right)_{2}(\mathrm{OMe})_{6}(781 \mathrm{~g} / \mathrm{mol})$, which is generated by aminophosphine solvolysis of residual methanol ${ }^{2}$ in the mass spectrometer.

Two additional peaks present in the spectra of post-nucleation samples $(\mathrm{m} / \mathrm{z}=1327,1674)$ contain -26 and -52 side peaks, characteristic of oleyl groups. The species with peak at $\mathrm{m} / \mathrm{z}=$ 1674 does not contain a metal or halogen, as this peak is also present in the mass spectra of the supernatants from $\mathrm{Cu}_{3-x} \mathrm{P}$ nanocrystals synthesized using $\mathrm{CuBr}$ instead of $\mathrm{CuCl}$ (Figure S6vi) and

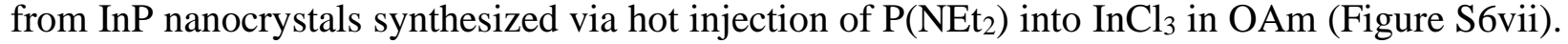
This species is tentatively assigned as $\left[\left(\mathrm{NHC}_{18} \mathrm{H}_{35}\right)_{3} \mathrm{P}\left(\mathrm{NC}_{18} \mathrm{H}_{35}\right) \mathrm{P}=\mathrm{O}\left(\mathrm{NHC}_{18} \mathrm{H}_{35}\right)_{2}\right]^{+}$. An analogous peak was observed at $m / z=1519$ with the expected $6 \times\left(\mathrm{R}-\mathrm{R}^{\prime}\right)$ mass difference of $156 \mathrm{~m} / \mathrm{z}$ from using $\mathrm{R}^{\prime}=$ hexadecylamine ${ }^{3}$ instead of $\mathrm{R}=\mathrm{OAm}$. Although the peak at $\mathrm{m} / \mathrm{z}=1327$ could not be identified, it is likely unique to the formation of $\mathrm{Cu}_{3-x} \mathrm{P}$. Notably, this peak is present in the mass spectrum of the supernatant from $\mathrm{Cu}_{3-x} \mathrm{P}$ nanocrystals synthesized using $\mathrm{CuBr}$ instead of $\mathrm{CuCl}$ (Figure S6vi), but not present in the supernatant from InP nanocrystals synthesized via hotinjection of $\mathrm{P}\left(\mathrm{NEt}_{2}\right)$ into $\mathrm{InCl}_{3}$ in $\mathrm{OAm}$ (Figure S6vii). 


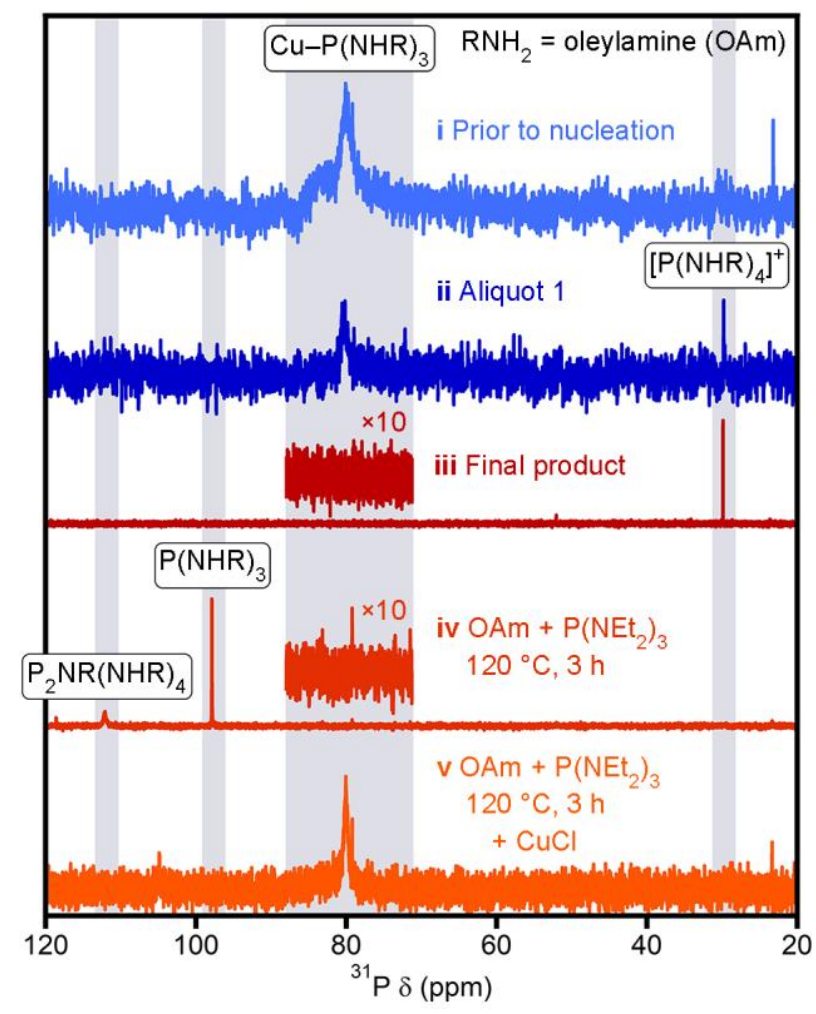

Figure S7. ${ }^{31} \mathrm{P}-\mathrm{NMR}$ spectra. (i-iii) One-pot synthesis of $\mathrm{Cu}_{3-x} \mathrm{P}$ nanocrystals ([Cu] $=0.100 \mathrm{M}, \mathrm{OAm} / \mathrm{P} / \mathrm{Cu}=24.0 / 3.0 / 1.0, T_{\mathrm{f}}=300{ }^{\circ} \mathrm{C}$; Figure 2): (i) aliquot "0" collected prior to ramp-up from $125^{\circ} \mathrm{C}$, (ii) the supernatant of aliquot 1 and (iii) the final supernatant. (iv) $\mathrm{OAm} / \mathrm{P}\left(\mathrm{NEt}_{2}\right)_{3}(22.8 / 3.0)$ degassed at $120{ }^{\circ} \mathrm{C}(3 \mathrm{~h})$ to yield the transaminated phosphine, $\mathrm{P}(\mathrm{NHR})_{3}$, to which (v) 0.25 equiv $\mathrm{CuCl}$ was added at room-temperature. These data suggest that the region centered at $80 \mathrm{ppm}$ contains $\mathrm{P}(\mathrm{NHR})_{3}$-coordinated $\mathrm{Cu}$ species ("Cu-P(NHR)$)_{3}$ "), such as $\mathrm{Cu}_{2} \mathrm{Cl}_{2} \mathrm{P}_{2}(\mathrm{NHR})_{6}$ or $\mathrm{CuCl}\left(\mathrm{P}(\mathrm{NHR})_{3}\right)_{2}$. 


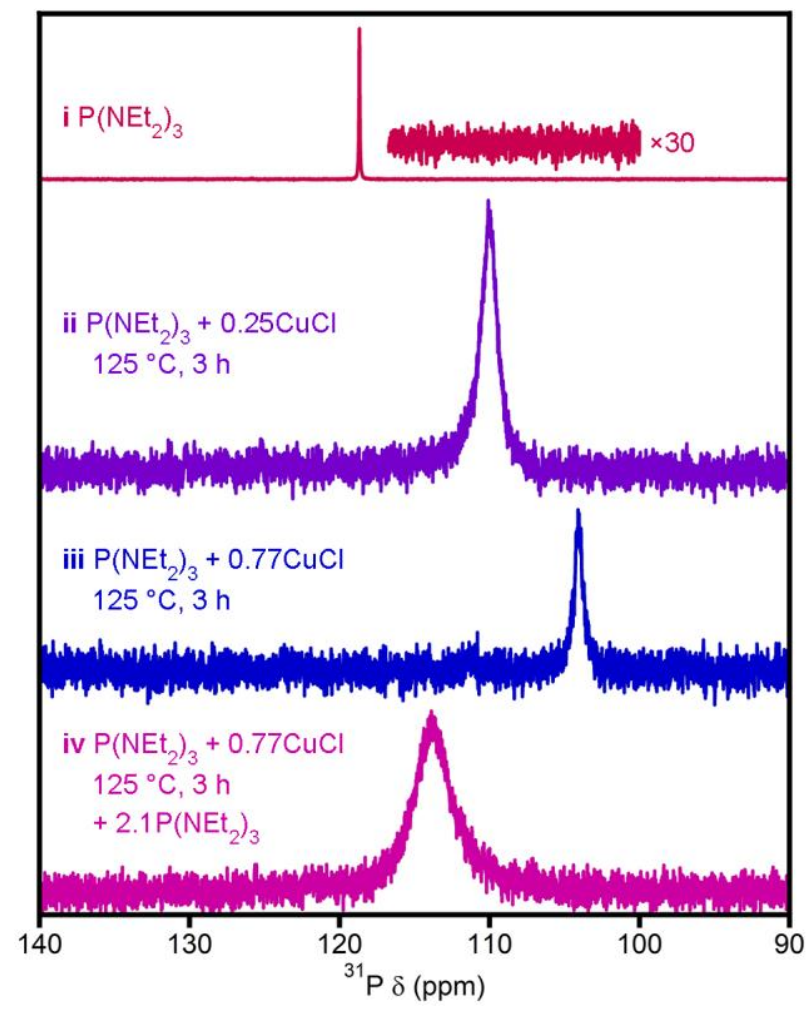

Figure S8. Monitoring of $\mathrm{Cu}$-phosphine complexation by ${ }^{31} \mathrm{P}-\mathrm{NMR}$. $\mathrm{P}\left(\mathrm{NEt}_{2}\right)_{3}$ (i) before and (ii, iii) after heating with $0.25,0.77$ equiv $\mathrm{CuCl}$ in octadecane at $125^{\circ} \mathrm{C}$ for $3 \mathrm{~h}$. Increasing addition of $\mathrm{Cu}$ results in an upfield shift of the $\mathrm{P}\left(\mathrm{NEt}_{2}\right)_{3}$ resonance. (iv) Addition of 2.1 equiv $\mathrm{P}\left(\mathrm{NEt}_{2}\right)_{3}$ shifts the resonance back downfield toward the free phosphine resonance. 


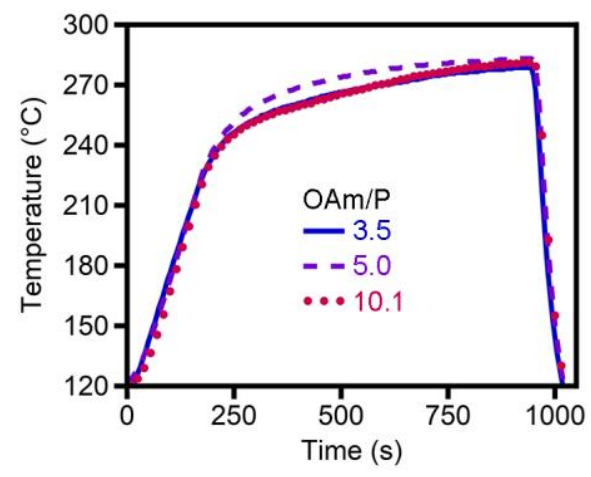

Figure S9. Temperature profiles for the syntheses of $\mathrm{Cu}_{3-x} \mathrm{P}$ nanocrystals with varying $\mathrm{OAm} / \mathrm{P}$ ratios $([\mathrm{Cu}]=0.100 \mathrm{M}, \mathrm{P} / \mathrm{Cu}=3.0$; Figure 3$)$

Table S2. Tabulated data for $\mathrm{Cu}_{3-x} \mathrm{P}$ nanocrystals synthesized with varying $\mathrm{OAm} / \mathrm{P}$ ratios $([\mathrm{Cu}]=$ $0.100 \mathrm{M}, \mathrm{P} / \mathrm{Cu}=3.0, T_{\mathrm{f}} \approx 280{ }^{\circ} \mathrm{C}$; Figures 1 and 3 ).

\begin{tabular}{cccccc} 
OAm/P & TOA/P & $\begin{array}{c}\text { Duration of } \\
\text { color change (s) }\end{array}$ & $\begin{array}{c}\text { Lateral } \\
\text { dimension }(\mathbf{n m})\end{array}$ & $\begin{array}{c}\text { LSPR energy } \\
(\mathbf{m e V})\end{array}$ & $\begin{array}{c}\text { Corresponding } \\
\text { TEM figure }\end{array}$ \\
\hline 3.5 & 5.0 & 50 & $4 \pm 1,10.1 \pm 0.9$ & 737 & $3 \mathrm{a}$ \\
5.0 & 3.9 & 50 & $15 \pm 1$ & 737 & $3 \mathrm{~b}$ \\
8.0 & 1.6 & 60 & $17 \pm 1$ & 776 & $1 \mathrm{c}$ \\
10.1 & 0 & 55 & $23 \pm 3$ & 786 & $3 \mathrm{c}$
\end{tabular}


Table S3. Yields of representative $\mathrm{Cu}_{3-x} \mathrm{P}$ syntheses with varying chemical conditions.

\begin{tabular}{|c|c|c|c|c|}
\hline $\begin{array}{l}\text { Chemical } \\
\text { conditions }\end{array}$ & $\begin{array}{c}\text { Yield }^{\mathrm{a}} \\
(\% \text { based on } \mathrm{Cu})\end{array}$ & $\begin{array}{c}\text { Lateral } \\
\text { dimension (nm) }\end{array}$ & $\begin{array}{c}\text { Relative nucleation } \\
\text { activity }^{\mathbf{b}}\end{array}$ & $\begin{array}{c}\text { Corresponding } \\
\text { TEM figure }\end{array}$ \\
\hline $\begin{array}{c}\mathrm{OAm} / \mathrm{P} / \mathrm{Cu}= \\
10.5 / 3.0 / 1.0 ; \mathrm{CuCl}\end{array}$ & $82 \pm 3$ & $4 \pm 1,10.1 \pm 0.9$ & $5-30^{c}$ & $3 a$ \\
\hline $\begin{array}{c}\mathrm{OAm} / \mathrm{P} / \mathrm{Cu}= \\
30.3 / 3.0 / 1.0 ; \mathrm{CuCl}\end{array}$ & $85 \pm 2$ & $23 \pm 3$ & 1 & $3 c$ \\
\hline $\begin{array}{c}\mathrm{OAm} / \mathrm{P} / \mathrm{Cu}= \\
11.2 / 1.4 / 1.0 ; \mathrm{CuCl}\end{array}$ & $54 \pm 2$ & $11 \pm 2$ & 3 & $4 a$ \\
\hline $\begin{array}{c}\mathrm{OAm} / \mathrm{P} / \mathrm{Cu}= \\
24.0 / 3.0 / 1.0 ; \mathrm{CuBr}\end{array}$ & $51 \pm 2$ & $14 \pm 1$ & 2 & S15 \\
\hline \multicolumn{5}{|c|}{$\begin{array}{l}{ }^{a} \text { Calculated as the percentage of } \mathrm{Cu} \text { used in the reaction that was incorporated into the } \\
\text { nanocrystal products } \\
{ }^{b} \text { Estimated as the ensemble particle count based on yield and lateral platelet dimension assuming } \\
\text { a constant platelet thickness. }\end{array}$} \\
\hline
\end{tabular}




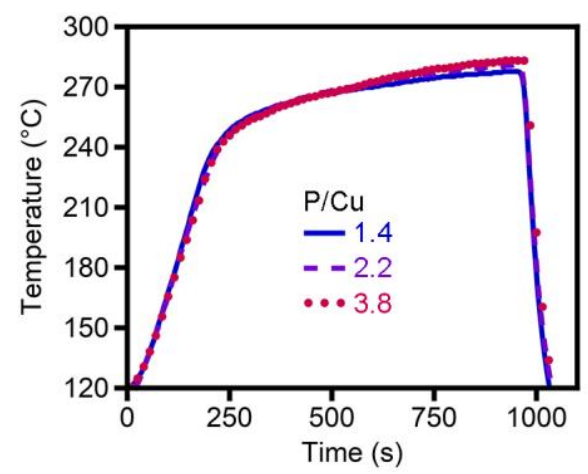

Figure S10. Temperature profiles for the syntheses of $\mathrm{Cu}_{3-x} \mathrm{P}$ nanocrystals with varying $\mathrm{P} / \mathrm{Cu}$ ratios $([\mathrm{Cu}]=0.100 \mathrm{M}, \mathrm{OAm} / \mathrm{P}=8.0$; Figure 4$)$.

Table S4. Tabulated data for $\mathrm{Cu}_{3-x} \mathrm{P}$ nanocrystals synthesized with varying $\mathrm{P} / \mathrm{Cu}$ ratios $([\mathrm{Cu}]=$ $0.100 \mathrm{M}, \mathrm{OAm} / \mathrm{P}=8.0, T_{\mathrm{f}} \approx 280{ }^{\circ} \mathrm{C}$; Figures 1 and 4 ).

\begin{tabular}{cccccc}
$\mathbf{P} / \mathbf{C u}$ & TOA/P & $\begin{array}{c}\text { Duration of } \\
\text { color change (s) }\end{array}$ & $\begin{array}{c}\text { Lateral } \\
\text { dimension }(\mathbf{n m})\end{array}$ & $\begin{array}{c}\text { LSPR energy } \\
(\mathbf{m e V})\end{array}$ & $\begin{array}{c}\text { Corresponding } \\
\text { TEM figure }\end{array}$ \\
\hline 1.4 & 10.3 & 120 & $11 \pm 2$ & 861 & $4 \mathrm{a}$ \\
2.2 & 4.3 & 100 & $13 \pm 2$ & 828 & $4 \mathrm{~b}$ \\
3.0 & 1.6 & 60 & $17 \pm 1$ & 776 & $1 \mathrm{c}$ \\
3.8 & 0 & 55 & $17 \pm 1$ & 761 & $4 \mathrm{c}$
\end{tabular}



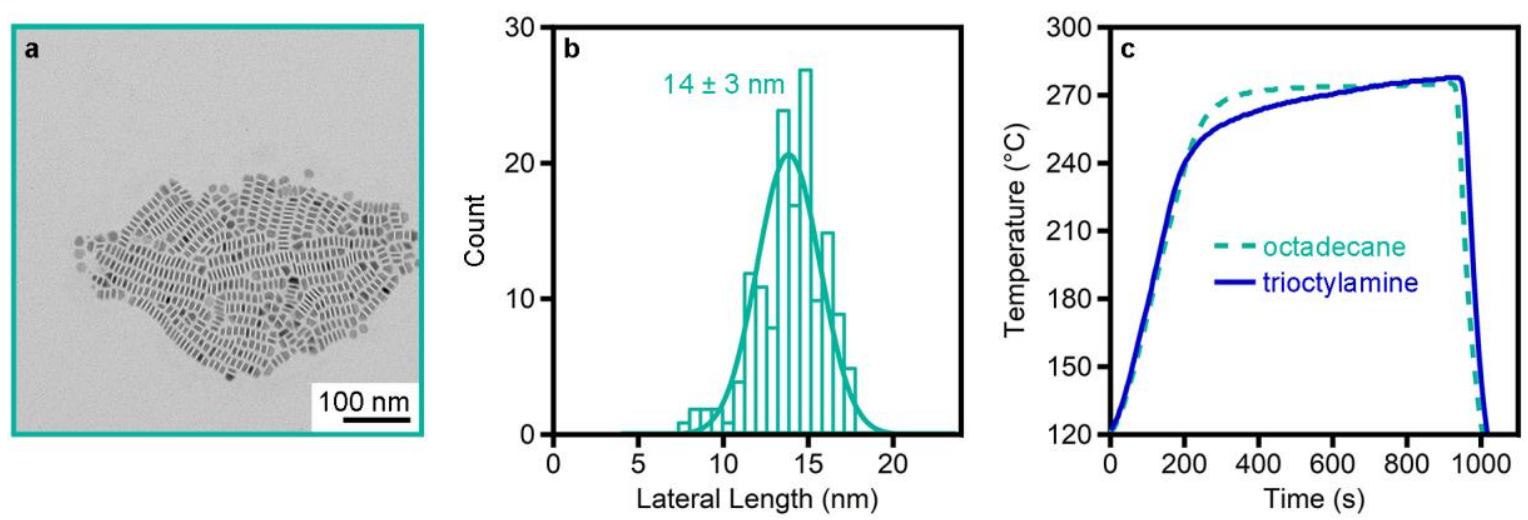

Figure S11. Characterization of $\mathrm{Cu}_{3-x} \mathrm{P}$ nanocrystals synthesized using octadecane $\left([\mathrm{Cu}]=0.100 \mathrm{M}, \mathrm{P} / \mathrm{Cu}=1.4, \mathrm{OAm} /\right.$ octadecane $\left./ \mathrm{P}=7.6 / 15.0 / 1.0, T_{\mathrm{f}}=275^{\circ} \mathrm{C}\right):(\mathbf{a})$ TEM image, (b) statistical analysis $(n=150)$ of lateral platelet dimension and (c) temperature profile compared to the analogous synthesis using TOA as the cosolvent $\left([\mathrm{Cu}]=0.100 \mathrm{M}, \mathrm{P} / \mathrm{Cu}=1.4, \mathrm{OAm} / \mathrm{TOA} / \mathrm{P}=8.0 / 10.3 / 1.0, T_{\mathrm{f}}=275^{\circ} \mathrm{C}\right.$; Figures $4 \mathrm{a}, \mathrm{S} 10)$. The analogous synthesis with TOA yielded nanocrystals with an ensemble lateral dimension of $11 \pm 2 \mathrm{~nm}$. 

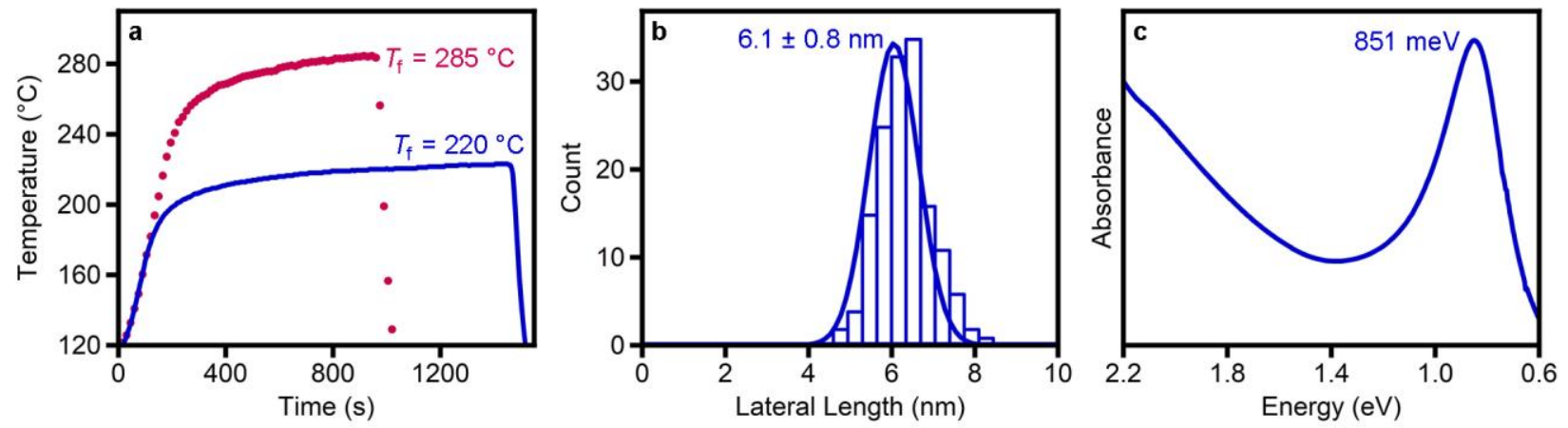

Figure S12. Characterization of $\mathrm{Cu}_{3-x} \mathrm{P}$ nanocrystals synthesized with $[\mathrm{Cu}]=0.100$ $\mathrm{M}$ and $\mathrm{OAm} / \mathrm{P} / \mathrm{Cu}=24.0 / 3.0 / 1.0$ at low temperature $\left(T_{\mathrm{f}}=220{ }^{\circ} \mathrm{C}\right.$, Figure 5): (a) Temperature profile compared to the one-pot high-temperature profile (reproduced from Figure 1c). (b) Statistical analysis of lateral platelet dimension and (c) absorption spectrum of the nanocrystal ensemble.

Table S5. Tabulated data for $\mathrm{Cu}_{3-x} \mathrm{P}$ nanocrystals synthesized with varying temperature profiles $([\mathrm{Cu}]=0.100 \mathrm{M}, \mathrm{OAm} / \mathrm{P} / \mathrm{Cu}=24.0 / 3.0 / 1.0$; Figures $1 \mathrm{c}, 5, \mathrm{~S} 1, \mathrm{~S} 12$ and S13).

\begin{tabular}{ccccc}
$\boldsymbol{T}_{\mathbf{f}}\left({ }^{\circ} \mathbf{C}\right)$ & $\begin{array}{c}\text { Duration of } \\
\text { color change }(\mathbf{s})\end{array}$ & $\begin{array}{c}\text { Lateral } \\
\text { dimension }(\mathbf{n m})\end{array}$ & $\begin{array}{c}\text { LSPR energy } \\
(\mathbf{m e V})\end{array}$ & $\begin{array}{c}\text { Corresponding } \\
\text { TEM figure }\end{array}$ \\
\hline 285 & 60 & $17 \pm 1$ & 776 & $1 \mathrm{c}$ \\
220 & 240 & $6.1 \pm 0.8$ & 851 & $5 \mathrm{a}$ \\
$275^{\mathrm{a}}$ & 270 & $22 \pm 2$ & 855 & $\mathrm{~S} 13 \mathrm{~b}$
\end{tabular}

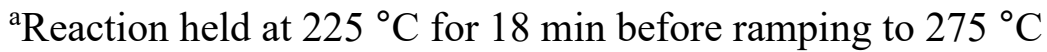



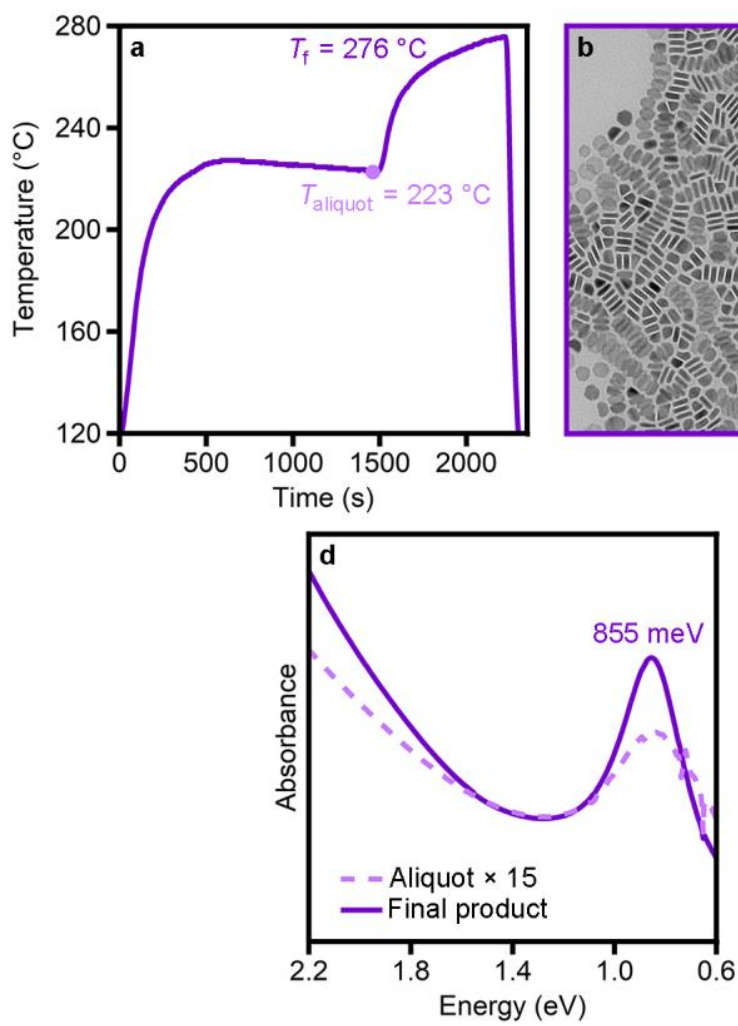
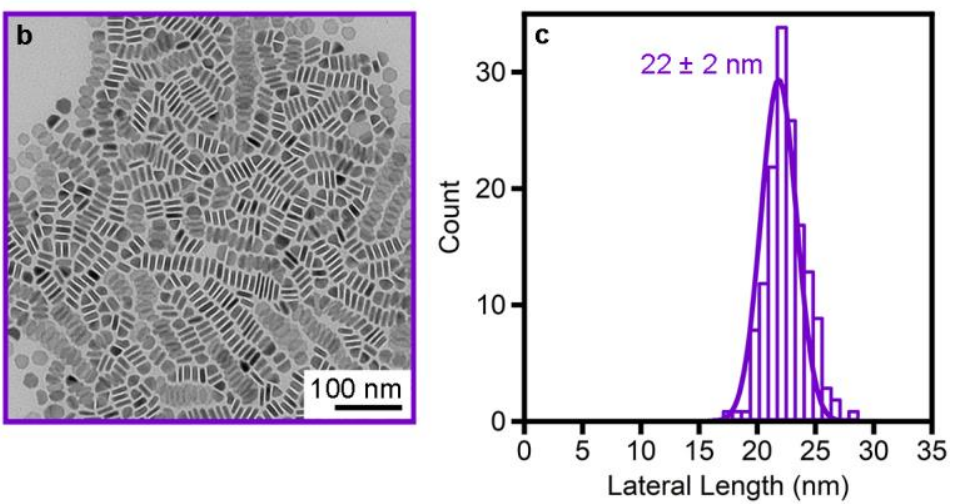

Figure S13. Characterization of $\mathrm{Cu}_{3-x} \mathrm{P}$ nanocrystals synthesized by heating at 225 ${ }^{\circ} \mathrm{C}$ for $18 \mathrm{~min}$ followed by heating to $T_{\mathrm{f}}=276^{\circ} \mathrm{C}([\mathrm{Cu}]=0.100 \mathrm{M}, \mathrm{OAm} / \mathrm{P} / \mathrm{Cu}=$ 24.0/3.0/1.0). (a) Temperature profile with aliquot withdrawal indicated (purple circle). (b) TEM image and (c) statistical analysis $(n=150)$ of lateral platelet dimension of the final nanocrystal product. (d) Quantitative absorption comparison of the aliquot and final product reveal $\sim 15 \times$ lower yield in the aliquot. (e) Powder $\mathrm{X}$-ray diffraction pattern of the final product compared to that simulated for $\mathrm{P}_{3} \mathrm{~cm}$ $\mathrm{Cu}_{2.87} \mathrm{P}$ (ref. 1). 

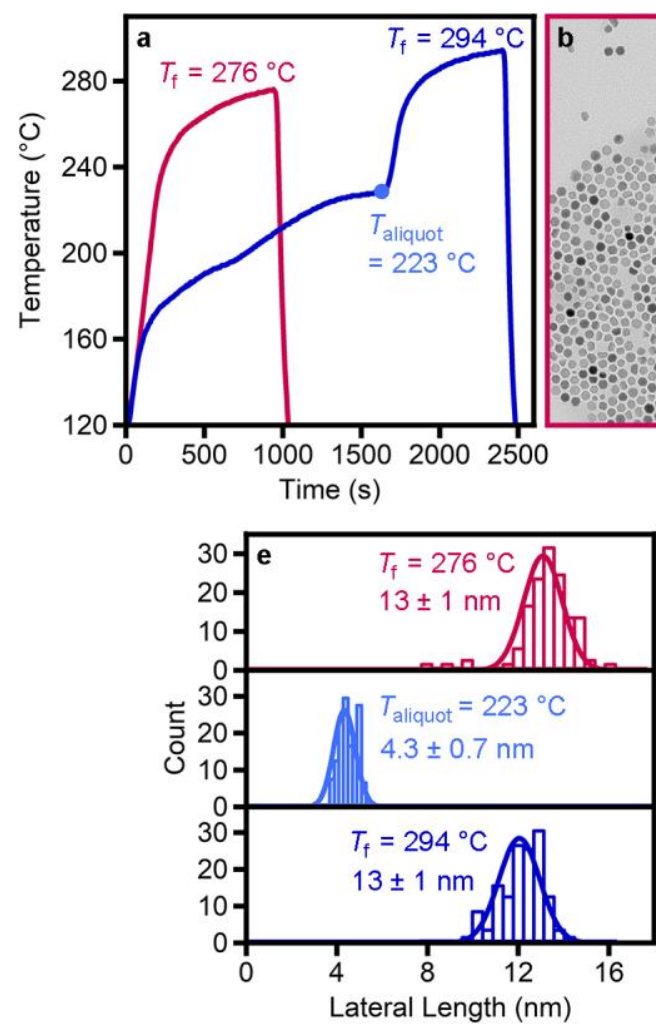
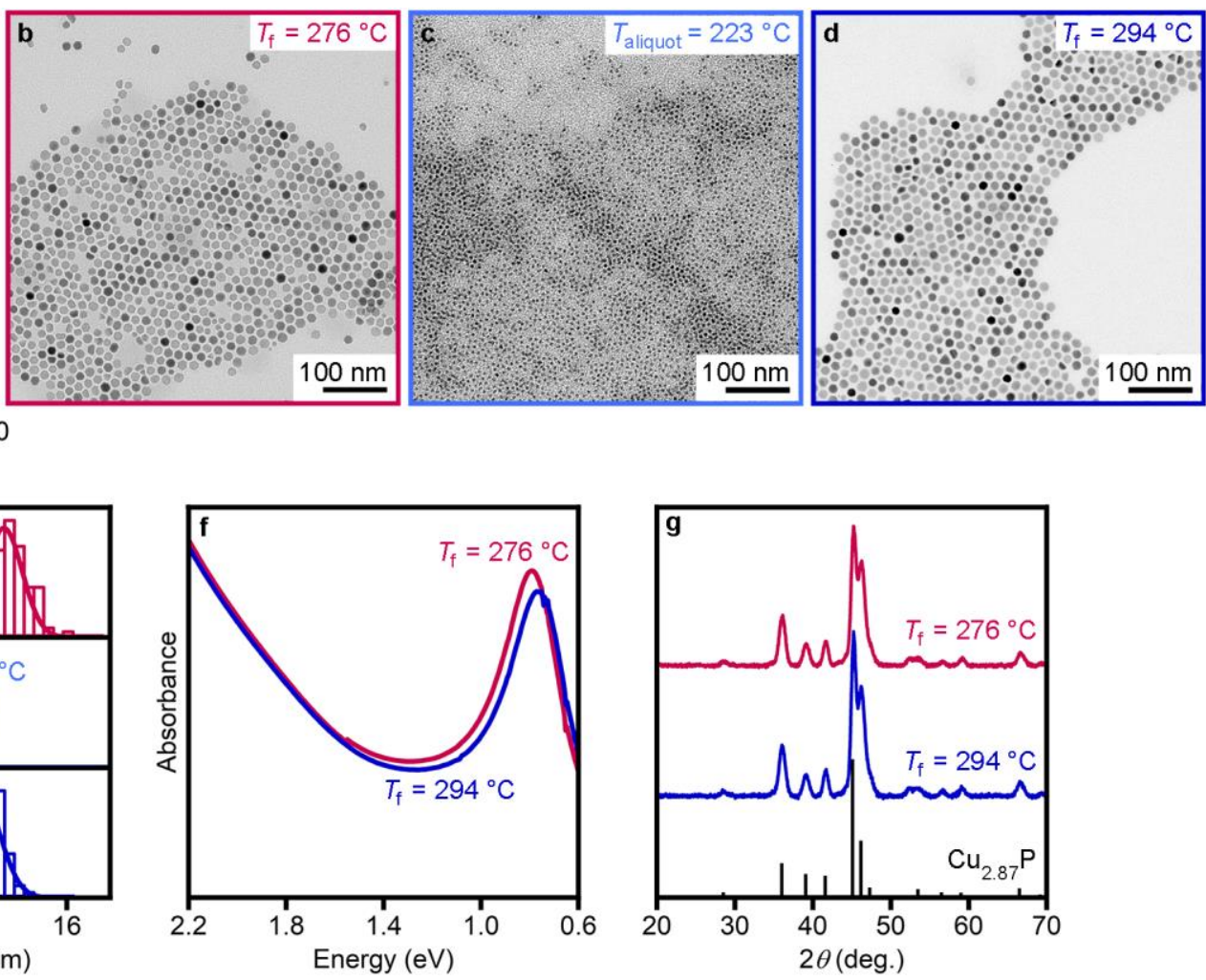

Figure S14. Characterization of $\mathrm{Cu}_{3-x} \mathrm{P}$ nanocrystals from two separate syntheses with $[\mathrm{Cu}]=0.100 \mathrm{M}$ and $\mathrm{OAm} / \mathrm{P} / \mathrm{Cu}=4.9 / 1.4 / 1.0$ using different temperature profiles. (a) Temperature profiles for both reactions with aliquot withdrawal indicated (blue circle). TEM images of $\mathrm{Cu}_{3-x} \mathrm{P}$ nanocrystals from (b) a quick-ramp synthesis $\left(T_{\mathrm{f}}=275^{\circ} \mathrm{C}\right)$, (c) an aliquot $\left(T_{\text {aliquot }}=223^{\circ} \mathrm{C}\right)$ taken prior to ramp-up and (d) the final product $\left(T_{\mathrm{f}}=294^{\circ} \mathrm{C}\right)$ of the two-part synthesis. (e) Statistical analyses $(n=150)$ of lateral platelet dimension for each nanocrystal set. (f) Quantitative absorption comparison of the two syntheses suggests similar final yield. (g) Powder $\mathrm{X}$-ray diffraction patterns compared to that simulated for $\mathrm{P}_{3} \mathrm{~cm} \mathrm{Cu}_{2.87} \mathrm{P}$ (ref. 1). 

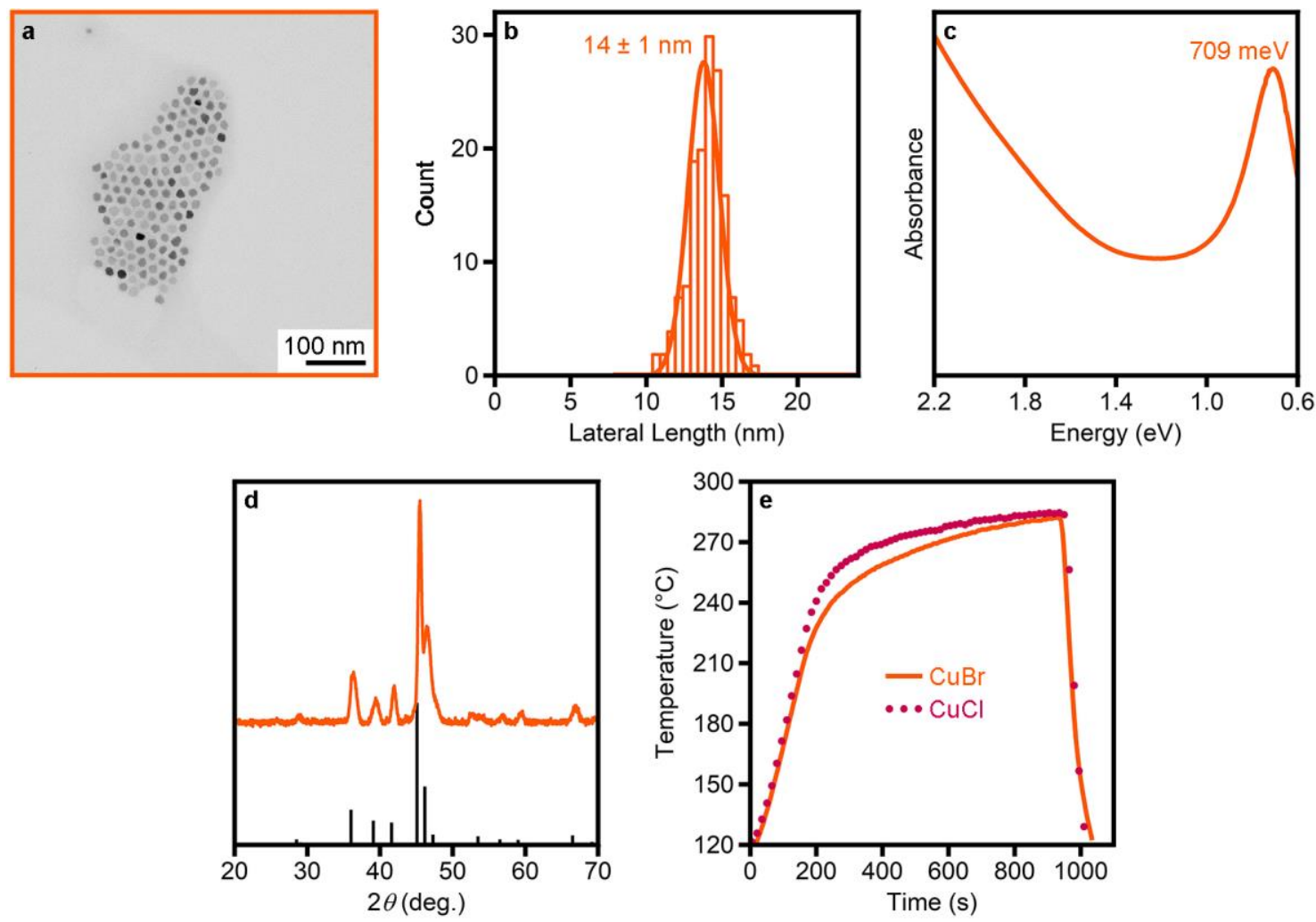

Figure S15. Characterization of $\mathrm{Cu}_{3-x} \mathrm{P}$ nanocrystals synthesized using $\mathrm{CuBr}([\mathrm{Cu}]$ $\left.=0.100 \mathrm{M}, \mathrm{OAm} / \mathrm{P} / \mathrm{Cu}=24.0 / 3.0 / 1.0, T_{\mathrm{f}}=285^{\circ} \mathrm{C}\right)$ : (a) TEM image, (b) statistical analysis $(n=150)$ of lateral platelet dimension, (c) absorption spectrum, (d) powder X-ray diffraction pattern (compared to that simulated for $\mathrm{P}_{3} c m \mathrm{Cu}_{2.87} \mathrm{P}$, ref. 1) and (e) temperature profile compared to the analogous synthesis using $\mathrm{CuCl}$ (Figure 1c).

Table S6. Tabulated data for $\mathrm{Cu}_{3-x} \mathrm{P}$ nanocrystals synthesized using various copper halides $\left([\mathrm{Cu}]=0.100 \mathrm{M}, \mathrm{OAm} / \mathrm{P} / \mathrm{Cu}=24.0 / 3.0 / 1.0\right.$ and $T_{\mathrm{f}}=285^{\circ} \mathrm{C}$; Figures $1 \mathrm{c}$ and S15).

\begin{tabular}{ccccc}
$\mathbf{X}^{-}$ & $\begin{array}{c}\text { Duration of } \\
\text { color change (s) }\end{array}$ & $\begin{array}{c}\text { Lateral } \\
\text { dimension }(\mathbf{n m})\end{array}$ & $\begin{array}{c}\text { LSPR energy } \\
(\mathbf{m e V})\end{array}$ & $\begin{array}{c}\text { Corresponding } \\
\text { TEM figure }\end{array}$ \\
\hline $\mathrm{Cl}^{-}$ & 60 & $17 \pm 1$ & 770 & $1 \mathrm{c}$ \\
$\mathrm{Br}^{-}$ & 50 & $14 \pm 1$ & 709 & $\mathrm{~S} 15$
\end{tabular}



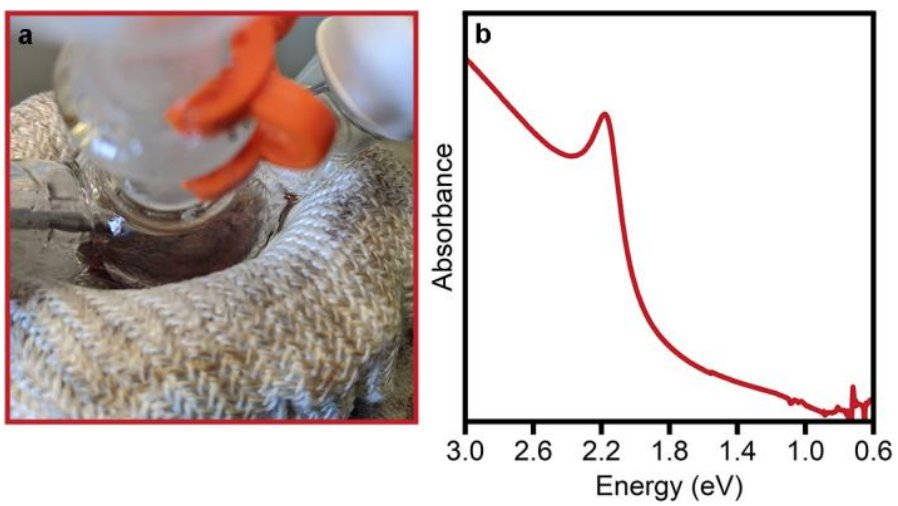

Figure S16. Characterization of $\mathrm{Cu}(0)$ nanocrystals nucleated in a one-pot synthesis with high-OAm and low-P(NEt $)_{3}$ content $([\mathrm{Cu}]=0.100 \mathrm{M}$ and $\mathrm{OAm} / \mathrm{P} / \mathrm{Cu}=30.4 / 1.4 / 1.0$ ): (a) Photograph of the red solution observed at $247^{\circ} \mathrm{C}$, signaling the initiation of $\mathrm{Cu}(0)$ formation and (b) absorption spectrum of an aliquot of $\mathrm{Cu}(0)$ nanocrystals withdrawn $60 \mathrm{~s}$ after the color-change. This red intermediate is not observed in other syntheses.
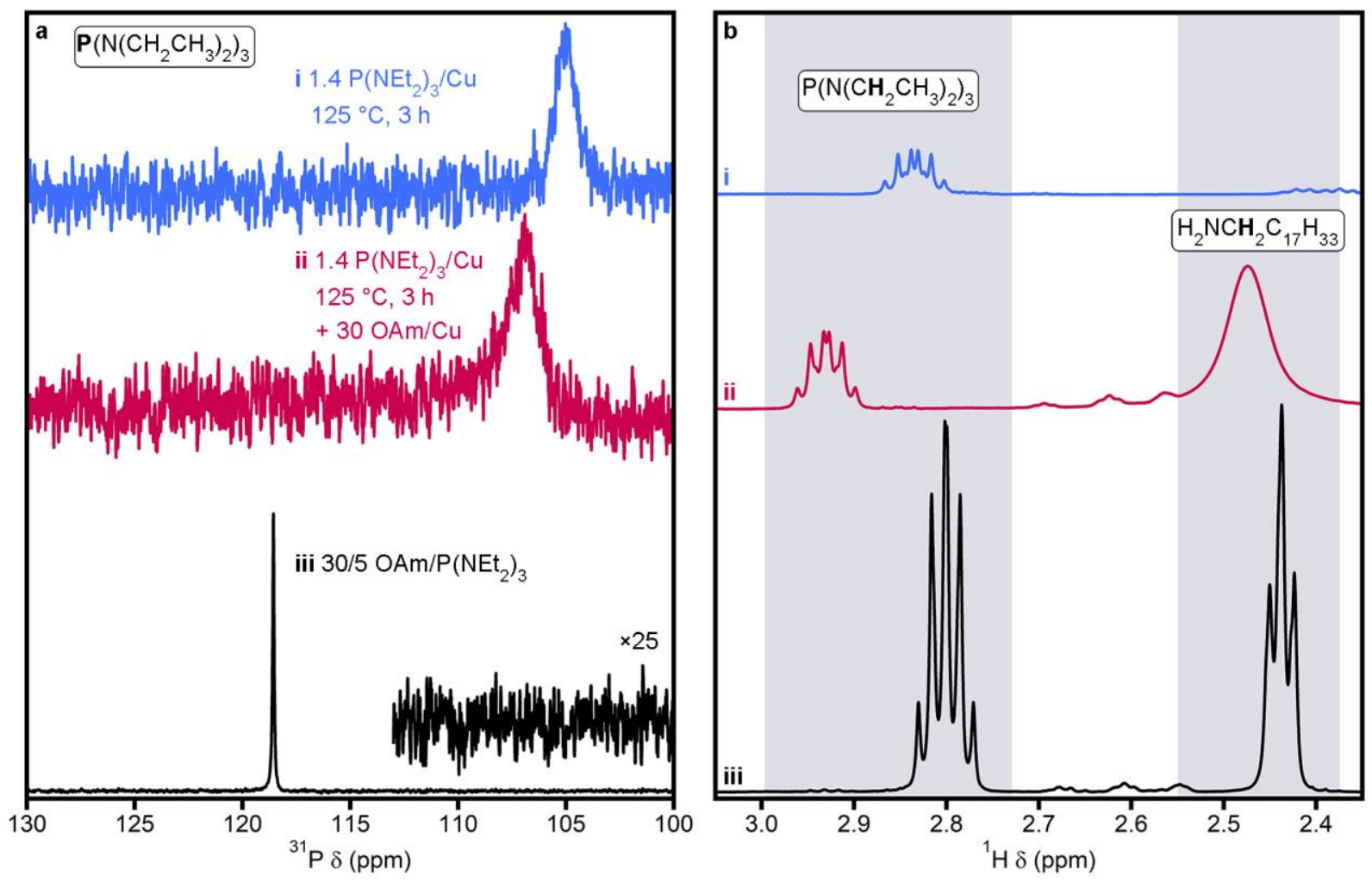

Figure S17. (a) ${ }^{31} \mathrm{P}$ - and (b) ${ }^{1} \mathrm{H}-\mathrm{NMR}$ spectra of $1.4 \mathrm{P}\left(\mathrm{NEt}_{2}\right)_{3} / \mathrm{Cu}$ with (i) 0 and (ii) 30 equiv $\mathrm{OAm}$. (iii) $30 / 5 \mathrm{OAm} / \mathrm{P}\left(\mathrm{NEt}_{2}\right)_{3}$ is shown for reference. 
Table S7. Chemicals

\begin{tabular}{|c|c|c|}
\hline Chemical & Purity & Manufacturer \\
\hline $\mathrm{d}^{6}$-Benzene & $99.5 \%$ & Cambridge Isotope Laboratories \\
\hline Copper(I) chloride & $>97 \%$ & Strem Chemicals \\
\hline Copper(I) bromide & $>98 \%$ & Strem Chemicals \\
\hline Oleylamine (OAm) & $>95 \%$ & Strem Chemicals \\
\hline Octadecane & $99 \%$ & Alfa Aesar \\
\hline Tris(diethylamino)phosphine $\left(\mathrm{P}_{\left.\left(\mathrm{NEt}_{2}\right)_{3}\right)}\right)$ & $95 \%$ & Acros Organics \\
\hline Trioctylamine (TOA) & $97 \%$ & Frontier Scientific \\
\hline
\end{tabular}

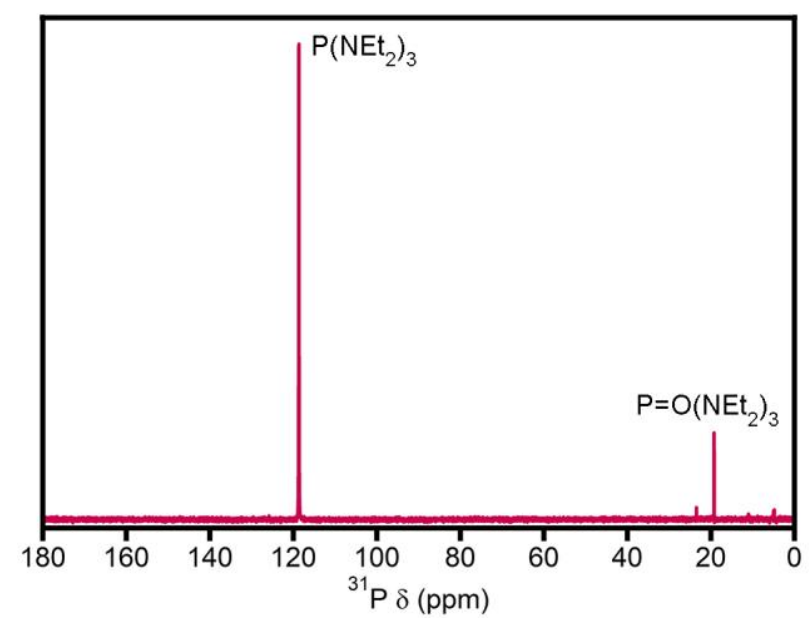

Figure S18. ${ }^{31} \mathrm{P}-\mathrm{NMR}$ spectrum of $\mathrm{P}\left(\mathrm{NEt}_{2}\right)_{3}$ after degassing and storage over molecular sieves $(4 \AA)$ for two days.

\section{References}

1. Olofsson, O. The crystal structure of $\mathrm{Cu}_{3}$ P. Acta. Chem. Scand. 1972, 26, 2777.

2. Tessier, M. D.; De Nolf, K.; Dupont, D.; Sinnaeve, D.; De Roo, J.; Z, H. Aminophosphines: A Double Role in the Synthesis of Colloidal Indium Phosphide Quantum Dots. J. Am. Chem. Soc. 2016, 138, 5923.

3. Buffard, A.; Dreyffuss, S.; Nadal, B.; Heuclin, H.; Xu, X.; Patriarche, G.; Mézailles, N.; Dubertret, B. Mechanistic Insight and Optimization of InP Nanocrystals Synthesized with Aminophosphines. Chem. Mater. 2016, 28, 5925. 